R OCZNIKI HUMANIST Y C Z N E

Tom LXIX, zeszyt 5 - 2021

ZESZYT SPECJALNY / SPECIALE UITGAVE

DOI: http://doi.org/10.18290/rh21695sp-9

DAMIAN OLSZEWSKI

\title{
NEDERLANDSE FANTASTISCHE LITERATUUR IN HET POOLS VERTAALD
}

\begin{abstract}
A bstract. De Nederlandse fantastische literatuur toont een duidelijke stijging in het proces van formaliseren en het ontwikkelen van een positie in de Nederlandse literatuur en cultuur. Dat blijkt ook uit de groeiende interesse van de buitenlandse literatuurmarkten. Dit artikel toont de geschiedenis en de tendenties van het vertalen van Nederlandse fantastische literatuur naar het Pools. Er worden de verschillende literaire organisaties, de subgenres en de vormen van het uitgeven van de Nederlandse fantastische literatuur in het Pools hierbij behandeld om de tendenties van de Poolse literaire sfeer te tonen.
\end{abstract}

Trefwoorden: sciencefiction; fantasy; fantastische literatuur; Willem Bilderdijk; Mike Jansen.

\section{INLEIDING}

Bij het bespreken van minder gepopulariseerde genres, auteurs en verschijnselen in de literatuur en cultuur hebben onderzoekers de neiging om de daarmee verbonden problemen uit te vergroten. In de laatste decennia van de $20^{\mathrm{e}}$ eeuw was het grootste probleem van de (Nederlandse) fantastische literatuur de marginalisatie van het genre in de Westerse wereld. Maar dat is aan het veranderen. De Nederlandse fantastische literatuur doet het namelijk steeds beter: het aantal Nederlandstalige schrijvers groeit en verschillende organisaties en tijdschriften organiseren verhalenwedstrijden en workshops voor jonge en getalenteerde schrijvers (www4). Het genre wordt ook tijdens colleges op universiteiten bestudeerd (www3). In 2019 verscheen er een

Mgr. Damian Olszewski is als promovendus verbonden aan de Szkola Doktorska van de Katolicki Uniwersytet Lubelski Jana Pawła II. Zijn onderzoek gaat van antropomorfische dieren in Nederlands proza. Daarnaast houdt hij zich bezig met Surinaamse orale literatuur, Nederlandse fantastische literatuur en jeugdliteratuur; correspondentieadres: Szkola Doktorska, Instytut Literaturoznawstwa WNH KUL, Al. Racławckie 14, 20-950 Lublin, Polen; e-mail: damian.olszewski@kul.pl; ORCID: https://orcid.org/0000-0002-2264-1373. 
reeks fantastische verhalen Dit is de toekomst in de Boeken \& Wetenschap afdeling van de Volkskrant (van Hal 4-6), wat een duidelijk signaal is dat dit genre niet meer genegeerd wordt.

Met die groei ontstaat er interesse van de kant van de auteurs, uitgevers en vertalers om dit genre naar andere culturen te brengen, wat ook nieuwe vragen en problemen genereert. Sinds 1990 duiden we een opmerkelijke groei aan het aantal uitgevers in Polen, wat een mogelijkheid bood aan auteurs en uitgevers om meer (buitenlandse) werken op de thuismarkt te brengen (Paszkiet 132-133). De popularisatie van het fantastische genre heeft ook natuurlijk te maken met de ontwikkeling van de populaire literatuur en met het intreden van het genre in de alledaagse discoursen, in principe via films en games (Oramus 13, 14). Door het popularisatie van het fantastische genre behoren ook de bekendste vertaalde literaire werken tot het fantastische genre (Harry Potter-series, het oeuvre van J.R.R. Tolkien), hoewel dat natuurlijk werken van buiten het Nederlandse taalgebied zijn (Paszkiet 134).

De komst van fantastische literatuur uit Nederland naar Polen staat ook zeker niet los van de geschiedenis van literaire vertalingen vanuit het Nederlands naar het Pools. Na de Tweede Wereldoorlog kregen de Nederlandstalige auteurs van alle genres dankzij de vermelde groei van het aantal uitgevers een kans om in Polen gepubliceerd te worden. Helaas werden vertalingen uit het Nederlands niet echt door de Poolse lezers geaccepteerd en waren ze relatief exotische literatuur. Door het dominerende aandeel van Engels-, Frans- en Duitstalige literatuur in Polen zijn vertalingen uit het Nederlands vooral van belang voor Neerlandici. Een typisch voorbeeld is het oeuvre van Harry Mulisch in Polen. Zijn werken kregen, apart van De procedure en De ontdekking van de hemel, slechts marginale interesse van Poolse lezers of de receptie ervan is zelfs negatief, hoewel hij wel een erkende auteur in het Nederlandse taalgebied is (Kalla 33, 34-45).

Een grote popularisator in Polen van Nederlandse literatuur (maar ook van literatuur uit andere minder bekende landen) is het tijdschrift Literatura na świecie, dat enkele nummers verbonden met Nederlandse auteurs publiceerde. Men vindt daar zowel besprekingen van voor Poolse lezers (on)bekende Nederlandse werken, als vertalingen van korte verhalen. De interessantste nummers zijn zeker die van maart 1976, mei 1978 en mei 1985 met de Nederlandse literatuur als hoofdthema (Czarnecka 15-19). Een ander interessant tijdschrift is Kresy, vooral het nummer uit 1996, dat ook veel Nederlandstalige werken in Poolse vertaling toonde (ibid. 20). Bożena 
Czarnecka (22) duidt aan, dat het aandeel van Nederlandse werken in Polen vanaf 2010 stagneert. Van de Poolse popularisatoren van de Nederlandse literatuur noemen we zeker Andrzej Dąbrówka, Jerzy Koch en Zofia Klimaszewska.

In dit artikel bekijken we na een inleiding over de Nederlandse fantastische literatuur wat de Nederlandse fantastische literatuur aan de Poolse lezers te bieden heeft. Op basis van de gepresenteerde gegevens wordt een korte analyse van deze vertalingen gegeven. Welke subgenres zijn het meest vertaald en door wie? Welke tussentaal is dominant in de Poolse markt van de Nederlandse fantastische literatuur? Is het mogelijk te bepalen welke volgende stappen in het populariseren van Nederlandse fantastische literatuur uitgevers en vertalers gaan nemen? De antwoorden op deze vragen kunnen een beeld geven van de tendens op de markt van Nederlands-Pools literair vertalen. Het artikel wil dan ook niet alleen de ontwikkeling van de Nederlandse fantastische literatuur in Polen tonen, maar ook enkele consequenties voor een toekomstige groei van dit genre laten zien.

\section{GENREBEPALING}

Bij een analyse van de fantastische literatuur is vooral nodig om het genre te definiëren. Op basis van de in de tweede helft van de $20^{\mathrm{e}}$ eeuw voorgestelde Nederlandse en Poolse definities van het fantastische genre is hieronder een poging gedaan om de kernelementen van het genre aan te duiden. Zowel Poolse als Nederlandse definities gaan in sterke mate uit van de Engelstalige definities, die onvermijdelijke bronnen zijn bij onderzoek naar het fantastische genre in Polen en Nederland (Majkowski 14, 15).

Helaas bestaan er weinig werken die Nederlandstalige fantastische literatuur behandelen. In het Algemeen Letterkundig Lexicon wordt een algemene definitie van de fantastische literatuur gegeven met als hoofdcriterium het doorbreken van de realiteit, de bovennatuurlijkheid. Onder fantastische literatuur vallen volgens dit naslagwerk ook subgenres als traditionele horrorverhalen, fantasy en sciencefiction, magisch realisme, reisverhalen en andere. Als gevolg van een dergelijke uitbreiding verwordt fantastische literatuur tot een umbrella term voor alle literaire werken, die om de een of andere reden niet passen binnen meer realistische werken (www5). Hetzelfde geldt voor de definitie voorgesteld door Van Gorp in het Lexicon van Literaire termen (141). Ook daar wordt gesteld dat het breken met de realiteit de 
hoofdzaak is, al is er hier wel een inperking van het genre: absurde, groteske en experimentele verhalen worden hier gescheiden van fantastische literatuur als zodanig.

De definitie van fantastische literatuur op basis van het criterium "afscheid nemen van de realiteit" wordt door de Poolse literaire traditie niet geaccepteerd (Majkowski 16). De lezer van fantastische literatuur wordt er immers niet van overtuigd dat de voorgestelde werelden en gebeurtenissen ooit waar gebeurd zijn. Deze teksten worden gelezen als sprookjes of als een verplaatsing van werkelijke relaties en conflicten tussen mensen, instituties en ideeën van de reële wereld naar een daarop lijkende wereld. Anders gezegd, de rol van de suspension of disbelief, een niet letterlijke overeenkomst tussen de auteur en de lezer om de fantastische realiaelementen aan te nemen (Lindeboom \& van der Zande 153), is cruciaal om de rol van het fantastische genre in de moderne wereldliteratuur goed te begrijpen. Aan de grond van de Poolse literatuurwetenschap duidt Grzegorz Trębicki aan dat het criterium van "afscheid nemen van de realiteit" wel kan aangepast zijn aan werken met surrealistische en bovennatuurlijke elementen. Daarbij behorende werken moeten echter duidelijk apart gesteld zijn van het exomimetische fantastische literatuur. De verwisseling van deze twee verschijnselen leidt vaak tot verdere problemen in verband met het definiëren van het fantastische genre (Trębicki 11).

Eenzelfde probleem zien we bij de bepaling van het genre en de vertegenwoordigers ervan bijvoorbeeld bij de Poolstalige geschiedenis van de Nederlandse literatuur van Dorota en Norbert Morciniec uit 1985. Bij de klassieke Nederlandse schrijvers van proza en poëzie wordt de plaats van de fantastische literatuur in de Nederlandse literaire wereld niet aangegeven. Toch komt de term sciencefiction wel aan bod in het geval van een paar schrijvers, namelijk: Willem Bilderdijk, Belcampo en Hugo Raes (Morciniec \& Morciniec 189, 327, 369). Ook in de Bloed en rozen. Geschiedenis van de Nederlandse literatuur 1900-1945 van Jacqueline Bel is er geen duidelijke informatie over het fantastische genre. In Altijd weer vogels die nesten beginnen. Geschiedenis van de Nederlandse literatuur 1945-2005 van Hugo Brems treffen we alleen aan het gebruik van het begrip fantastisch genre aan als een middel om dit van het magisch realisme te onderscheiden (Brems 164-169). Toch is de term "fantastisch" ook gebruikt bij het bespreken van enkele auteurs (bijv. Hugo Raes) (Brems 337) of uitgevers (ibid. 612). Het ontbreken van de fantastische literatuur in moderne besprekingen geldt wellicht het meest voor de theoretische werken uit Nederland. 
In recentere Nederlandse wetenschappelijke publicaties komt Willem Bilderdijk, de voorvader van de Nederlandse fantastische literatuur, wel aan bod met zijn Kort verhaal van eene aanmerkelijke luchtreis en nieuwe planeetontdekking, uit Russisch vertaald uit 1811/13. Dit korte verslag van een fantastische tocht met een ballon naar een object in de ruimte tussen Aarde en Maan is een mijlpaal van zowel de Nederlandse fantastische literatuur, als van de geografische verhalen ingeleid door Jules Verne 50 jaar later (van den Berg \& Couttenier 87). Door fantaseren over mogelijk gebruik van spectaculaire technische ontwikkelingen is Kort verhaal een van de vroegste vertegenwoordigers van het sciencefiction genre.

De door Bilderdijk gecreëerde wereld omvat echter niet het hele fantastische genre. Martijn Lindeboom en Debbie van der Zande $(11,12)$ duiden als de belangrijkste kenmerken van de fantastische literatuur het gebruik van fantastische (magische, bovennatuurlijke etc.) elementen aan. Deze elementen moeten ook in een realistisch aandoende wereld voorkomen, zodat de lezer zich ermee kan identificeren. De fantastische verhalen aspireren nooit om realistische verhalen te zijn. De avonturen en werelden in de fantastische genres vervullen een andere functie - ze mogen wel inspireren of moraliseren, maar zullen nooit als een volksverhaal of een religieuze tekst gezien worden (Lindeboom \& van der Zande 17).

De lezer en de auteur sluiten bij het beleven van de verhalen samen een onuitgesproken overeenkomst, namelijk dat bepaalde elementen in door de auteur als reaůistisch voorgestelde wereld wel mogelijk zijn. De taak van de auteur is om die fantastische wereld innerlijk logisch te maken. Om die reden moeten de realia door een wet worden ondersteund (Lindeboom \& van der Zande 153). Het beste voorbeeld is het sciencefiction genre, dat altijd op ten minste één voorstelbare uitvinding is gebaseerd, die de avonturen stimuleert. In de fantasy en horrorliteratuur komen deze stimulatoren bijvoorbeeld uit elementen van volksverhalen. Het fantastische genre is dus niet alleen met zijn literaire kenmerken verbonden, maar is afhankelijk van de al vroeger bestaande genres en tradities (Zgorzelski 17). Volgens analyses van Andrzej Zgorzelski en later van Dominika Oramus bestaat de kern van het fantastische genre uit het doorbreken van al bestaande literaire clichés met een verbazingwekkend element. Naarmate op zo'n manier standaardisering van een nieuw (sub)genre ontstaat, moet er nog een keer een vergelijkbare proces van de doorbreking van clichés gerealiseerd worden om het idee van fantastische verbazing te mogen leveren aan het steeds evoluerende lezerspubliek (Zgorzelski 28-30; Oramus 53-54). 
Traditioneel wordt het fantastische genre in drie subgenres onderverdeeld: fantasy (imaginaire werelden uit het verleden of het heden), sciencefiction (een technologisch anders ontwikkelde wereld van nu of uit de toekomst) en horrorverhalen (verhalen met gebruik van griezelelementen en angst die als hoofdfactor bij het creëren van de karakteristieke stemming dienen). In Nederland wordt ook het magisch realisme vaak als een vierde subgenre gerekend (Lindeboom \& van der Zande 11). Dit blijkt in het PoolsNederlands onderzoek echter problematisch te zijn. Hoewel het magisch realisme in de Nederlandse literatuurwetenschap wel als genre erkend wordt, is dat in de Poolse literatuurwetenschap anders (Pindel 27). Het magisch realisme krijgt hier wel de status van een literaire stroming, tendentie of stijl, maar niet die van een genre. De kenmerken ervan zijn het gebruik van hallucinaties, geestesziektes (Lindeboom \& van der Zande 11) en verschillen in de perceptie van de wereld (Pindel 36-40). In verband met deze onduidelijkheid in de Pools-Nederlands relaties binnen dit genre, is het essentieel om het magisch realisme wel te analyseren.

Een ander criterium dat onder de loep moet worden genomen is dat van de doellezer van het fantastische genre. Dit criterium valt samen met de vraag of fantastische literatuur van de jeugdliteratuur onderscheiden moet worden en in dit geval is de lezer het selectiecriterium. Jeugdliteratuur betreft per definitie een concrete groep lezers van ongeveer 6 tot 16 jaar oud (Van Bork 477, 496-498). Jeugdverhalen kunnen fantastische elementen bevatten, waardoor deze werken ook tot de fantastische literatuur gerekend kunnen worden. De fantastische literatuur is in de moderne opvatting echter nauwer gedefinieerd en heeft oudere lezers als doelgroep. In tegenstelling tot de jeugdliteratuur mogen we dan stellen, dat de fantastische literatuur voor lezers vanaf 16 jaar oud bestemd is, vooral vanwege het gebruik van motieven en symbolen die voor een jongere lezer (meestal) onbekend zijn. Hierdoor kan de lezer de tekst verkeerd begrijpen of interpreteren. Interesse in het creëren van boeken bestemd en beschikbaar voor jongere lezers is ook een kenmerk van de zeventiende eeuw (Van Bork 496-497), terwijl de eerste fantastische werken pas in de negentiende eeuw verschijnen (Van Bork 344). In deze bijdrage behandelen we daarom de jeugdliteratuur niet. 


\section{CRITERIA VAN DE GEKOZEN WERKEN}

De tabel in de bijlage aan het einde van dit artikel bevat een zo compleet mogelijk overzicht van vertaalde fantastische literaire werken van Nederlandse auteurs naar het Pools. Op basis van deze gegevens kan men tot belangrijke conclusies komen en de tendenties van de Poolse uitgevers (verbonden vooral met fantastische literatuur) aangeven. Bovendien fungeert het overzicht als een literair-historische bron voor verder onderzoek verbonden met dit thema.

De criteria voor de keuze van de geanalyseerde werken zijn als volgt:

- het behoren tot ten minste één van de subgenres van de fantastische literatuur of tot het magisch realisme;

- het duidelijke onderscheid van andere genres, die fantastische elementen gebruiken;

- de keuze van een adolescent als doellezer.

De hiervoor benodigde gegevens zijn verzameld op basis van:

- de lijst van in het Pools vertaalde Nederlandse literatuur van Małgorzata Dowlaszewicz en Jerzy Koch (Dowlaszewicz \& Koch, 588-628),

- lijsten van literaire werken uit het Nederlands naar het Pools vertaald, opgesteld door de medewerkers van de Katholieke Universiteit te Lublin (www7),

- lijsten op de Poolse pagina Encyklopedia Fantastyki (www2), een encyclopedie opgesteld door fantasy-fans,

- lijsten van werken vertaald door de leden van Poolse vereniging van literaire vertalers Stowarzyszenie Tłumaczy Literatury (www1),

- eigen onderzoek op basis van de archivale nummers van de hieronder gepresenteerde tijdschriften en magazijnen.

In deze bijdrage zijn werken zonder een ISBN- of ISSN-nummer buiten beschouwing gelaten en worden alleen literaire werken geanalyseerd, die professioneel uitgegeven zijn. Deze keuze houdt verband met het feit dat fantasyliefhebbers actief in verschillende aspecten van al gepubliceerde teksten willen kunnen ingrijpen. Als gevolg daarvan ontstaan er veel nieuwe werken, vertalingen en bewerkingen die worden gepubliceerd zonder winstoogmerk op blogs en daarvoor bestemde pagina's (bijvoorbeeld Fantasywereld.nl; www6). Op deze manier, dat wil zeggen met gratis publicaties, beginnen ook de professionele vertalers en auteurs van fantasy te werken om meer kritiek te krijgen en om hun vaardigheden op te bouwen. Dit soort werken zijn niet professioneel gepubliceerd en worden door lezers ook als niet-officiële werken beschouwd. 


\section{BESPREKING TABEL}

Tijdens het onderzoek zijn er 77 teksten van Nederlandse en Vlaamse auteurs gevonden, die naar tenminste één subgenre van het fantastische genre verwijzen. Daarbij gaat het om zowel langere (novelles, romans) als kortere (verhalen, poëzie) tekstsoorten. De teksten zijn via twee grote talen (Frans, Engels) of rechtstreeks uit het Nederlands naar het Pools vertaald. Er is echter ook een reeks teksten waarbij het niet mogelijk is te bepalen uit welke taal ze vertaald zijn. Dit probleem doet zich voor bij het Poolse tijdschrift Szortal (www8), dat wel graag Nederlandse auteurs vertaalde, maar als een zin - een werk gebaseerd op het vrijwilligerswerk van fantasyliefhebbers dat gratis beschikbaar is (Boekstein 32). Bovendien is één van de magisch realistische romans (Het gouden ei van Tim Krabbé) tweemaal vertaald uit twee verschillende talen. Voor het onderzoek zijn deze uitgaven als twee aparte werken gerekend.

De dominerende brontaal is het Nederlands (43 werken - bijna 56\%). Het Engels is het vaakst als tussentaal gebruikt (9) en verder het Frans (1). Bij de overige teksten (24) is de brontaal niet aangegeven. Omdat er vertalers beschikbaar zijn die met Nederlandstalige fantastische literatuur kunnen werken, is er een duidelijke tendentie bij uitgevers om vanuit de originele taal te laten vertalen (hoewel dat geen vaste regel voor Poolse uitgevers is). Wellicht zijn zij zich bewust van mogelijke consequenties van het gebruik van een tussentaal bij literair vertalen (Filkins 88). Zelfs als we aannemen dat alle door Szortal vertaalde werken uit het Engels vertaald zijn, is dit aantal (33 werken) nog steeds lager dan het aantal werken dat direct uit het Nederlands vertaald is.

Qua vorm is de overgrote meerderheid van de vertaalde werken een (kort) verhaal (65 teksten - meer dan 84\%). Van deze verhalen verschenen er 46 in bundels en de rest (19) in tijdschriften. De overige teksten zijn romans (6), één novelle en één gedicht. Deze laatste wordt hier ook meegerekend vanwege de plaats van uitgave (het tijdschrift Szortal was exclusief bestemd voor het fantastische genre) en het oeuvre van de auteur. De 4 laatste werken zijn qua vorm niet meer te definiëren vanwege de beperkte toegang tot niet meer online beschikbare nummers van het tijdschrift Szortal. Wellicht zijn het korte vormen, omdat dat in principe het doel van Szortal (Szortal $=$ short stories portal) was. Op basis van deze vergelijking zien we dat de korte vormen de meest vertaalde werken zijn. Dat kan ermee verband houden, dat korte teksten sneller kunnen worden vertaald. De kans is groter dat een 
vertaler tijd voor het bewerken van een kortere tekst zal vinden dan voor een roman. Op die manier kunnen vertalers in dezelfde tijd meer werken in een doeltaal leveren dan bij het vertalen van langere teksten. Met een grotere frequentie van het verschijnen van de teksten van dezelfde auteur komt de lezer de naam van de auteur (en van de vertaler) vaker tegen, wat als een promotiestrategie gezien kan worden. De meeste verhalen (41 teksten - meer dan $53 \%$ van alle teksten, meer dan $63 \%$ van de korte verhalen) werden gratis uitgegeven - de tijdschriften en bundels waarin ze staan zijn (of waren) gratis beschikbaar en zijn uitgegeven met het doel om (ook) Nederlandse fantastische literatuur te bevorderen. Een andere factor die hier dus ook ter sprake komt, is de financiële kwestie. De auteurs stellen liever hun kortere teksten gratis ter beschikking dan hele romans met de bedoeling om hun werk te promoten zonder extra kosten te dragen. Hetzelfde geldt voor de uitgevers. Voor hen is de uitgave van een hele roman van een minder bekende auteur in Polen een financieel risico. Dat hangt ook samen met de kwestie van de auteursrechten, die bij commerciële uitgaven betaald moeten worden.

Bij het bepalen van het subgenre van de verhalen zijn sommige teksten bij meer dan één subgenre gerekend vanwege het gebruik van de aanwezigheid van kenmerken, die representatief zijn voor verschillende subgenres. In dit geval zal het aantal genres hoger zijn dan het aantal vertaalde werken. Ook hier kunnen de vier onbepaalde teksten niet gecategoriseerd worden door het gebrek aan informatie erover. Het (lichtelijk) dominerende subgenre is de fantasy met 35 teksten. Daarna volgt sciencefiction met 26 teksten. De twee andere subgenres zijn duidelijk minder populair - horror met 13 teksten en het magisch realisme met 10 teksten. Het gebrek aan vertaalde magisch realistische teksten kan samenhangen met de boven vermelde problematische status van het magisch realisme in Polen, dat niet erkend is als genre. Bij de horrorliteratuur is dit gebrek echter moeilijker uit te leggen. De populariteit van alle drie subgenres is meestal vergelijkbaar, hoewel het vertalen van horrorverhalen wat moeilijker kan zijn bij het doorgeven van de sfeer.

\section{AUTEURS, VERTALERS EN UITGEVERS}

De volgende stap van de analyse is een statistiek verbonden met de mensen die voor het leveren van de teksten verantwoordelijk zijn: auteurs en vertalers. Van de meeste schrijvers zijn er slechts 1-3 teksten in het Pools 
gepubliceerd ( 24 van de 29 auteurs). Er bestaat ook een groep auteurs van wie er 4 of 5 teksten in het Pools zijn gepubliceerd, wat kan betekenen dat ze in Polen erkend zijn als bekendere Nederlandse of Vlaamse fantasy schrijvers. Alleen van Mike Jansen zijn er liefst 24 verhalen in het Pools vertaald, wat hem tot de meest vertaalde Nederlandse schrijver van fantastische literatuur in Polen maakt. Al zijn verhalen zijn gratis gepubliceerd in tijdschriften en bundels. Zijn positie in de markt lijkt zo stabiel te zijn, dat hij mogelijk met succes commercieel uitgegeven zou kunnen worden in het Pools en niet alleen in gratis uitgaven.

Ook vertalers kunnen op basis van aantallen vertaalde teksten op een vergelijkbare manier worden verdeeld. De grootste groep vertalers (met slechts 1-3 vertaalde teksten) bestaat uit 33 vertalers. De vier andere vertalers hebben 5-8 korte verhalen vertaald. Op basis van de informatie over de auteurs, vertalers en hun teksten neem ik aan dat het vertalen van de Nederlandse fantastische literatuur nog een experiment voor veel auteurs en/of vertalers is, dat zelden herhaald wordt. De vertaalprojecten worden elke keer door een andere groep vertalers ondernomen en slechts vier vertalers blijken er op dit moment meer aandacht voor te hebben, zoals bij de Nederlandse literatuur in Polen in het algemeen.

Bij het tellen van de uitgevers en hun marktaandeel zijn enkele ervan samen gerekend, bijvoorbeeld de gewone uitgave van Szortal (Szortal na wynos) en de speciale uitgaven, of op dezelfde manier de speciale en gewone nummers van Nowa Fantastyka. Van de 13 uitgevers/ tijdschriften kozen alleen vijf ervoor om meer dan één of twee teksten van het fantastische genre te laten vertalen, hoewel de vertaalde teksten vaak in de bundels staan, die teksten uit de Nederlandse literatuur verzamelen zonder een genre als een hoofdmotief. Het gaat daarbij om uitgevers die geïnteresseerd zijn in de klassieke of minder bekende literatuur onafhankelijk van het taalgebied (bijvoorbeeld Ha!art) of in fantastische literatuur onafhankelijk van het taalgebied (bijvoorbeeld Rebis). Dat ondersteunt de theorie dat het uitgeven van dit type literatuur in Polen een poging om iets exotischs en onbekends aan de Poolstalige lezers te bieden.

De uitgevers/tijdschriften die meer dan andere met het fantastische genre uit Nederland werken zijn: Państwowe Wydawnictwo "Iskry" (5 teksten), Państwowy Instytut Wydawniczy (16 teksten), Grupa Wydawnicza Alpaka (20 teksten) en Szortal (22 teksten). De drie eerste uitgevers kozen ervoor om bundels met Nederlandse fantastische (of bovennatuurlijke) teksten uit te geven. In dit geval gaat het dus om een eenmalige publicatie in tegenstelling 
tot bij Szortal, dat als tijdschrift regelmatig vertaalde teksten publiceerde. De pogingen om de Nederlandse fantastische literatuur in Polen te publiceren is dus van de kant van de uitgever bijna altijd een eenmalig project. Bij deze vier uitgevers zijn echter verschillende drijfveren te bemerken. "Iskry" koos voor de literatuur voor jongens in het algemeen en een vertaling uit het Nederlandse taalgebied was zeker uniek. Grupa Wydawnicza Alpaka en Szortal kiezen ervoor om alleen fantastische literatuur uit te geven met een voorkeur voor sciencefiction en fantasy genres. Państwowy Instytut Wydawniczy kiest voor werken van wereldwijd beroemde schrijvers, waarbij auteurs en werken in talen met een groter aantal sprekers, bijvoorbeeld het Engels, Frans of Russisch worden geprefereerd.

De als eerste uitgegeven boeken in het Pools van deze lijst behoren tot het magisch realisme (1968 en 1979) en vier fantasy en/of horror verhalen (1975 en 1976). In de jaren ' 80 verschenen er één roman en twee bundels, die tezamen 20 teksten bevatten. In 1994 en 2002 verscheen nog Het gouden ei in twee vertalingen. Na deze vertalingen is er een duidelijke lijn zichtbaar de daaropvolgende vertalingen verschenen pas in 2013, niet meer in grotere boekuitgaven, maar als korte verhalen in verschillende tijdschriften. Deze vertalingen worden ook regelmatiger gepubliceerd en tonen de groeiende populariteit van het vertalen van teksten uit minder grote talen. Vanaf 2015 zijn er regelmatig ongeveer zes teksten per jaar uit de Nederlandse fantastische literatuur naar het Pools vertaald met een eenmalige sterke groei tot 22 teksten in 2018 door de publicatie van nog een andere bundel - Za tama. Fantastyka niderlandzka $w$ praktyce $i w$ teorii. Omdat Szortal is gestopt, is het aantal gepubliceerde fantastische werken uit Nederland in 2019 sterk gedaald tot maar 6 - vier verhalen, één novelle en één onbepaalde vorm.

De conclusie hier is dat de meeste vertaalde werken pro publico bono gepubliceerd zijn en dat de plotselinge groei in de laatste jaren een effect is van het werk van maar één uitgever. Hoewel er na het stoppen van Szortal minder verhalen gepubliceerd zullen worden, is dat ook een goed moment voor andere uitgevers om er meer aandacht aan te besteden - er is nu een niche op de markt. Ook het feit dat Szortal niet met het uitgeven van het Nederlandse fantastische genre stopte (toen ze nog nieuwe nummers uitgaven), is een signaal dat deze werken wel gelezen werden. Szortal stopte er namelijk mee alleen omdat de uitgever het tijdschrift in een uitgeverij wil omvormen, wat met grotere kosten verbonden is (Szortal - wsparcie finansowe). De genoemde niche kan succesvol ingevuld worden zonder veel risico op een daling van de interesse in dit genre. 


\section{CONCLUSIE}

Uit de hierboven vermelde gegevens kunnen we concluderen dat tijdschriften zonder winstoogmerk de grootste invloed op de popularisering van de Nederlandse fantastische literatuur tussen Poolse lezers hadden, maar ook vestigen een brug tussen Poolse en Nederlandse schrijvers, vertalers en uitgevers, die zeker verbouwd kan worden. Hoewel het aandeel van de fantastische verhalen in de bundels groot is, hadden de verhalen in tijdschriften een grotere invloed op het populariseren van de Nederlandse fantastische literatuur, omdat er door de jaren heen steeds een aantal werken gepubliceerd zijn. Bij bundels bestaat er altijd het gevaar dat deze verhalen na publicatie vergeten zullen worden, terwijl tijdschriften (door voortdurende publicatie) de namen van de auteurs op de markt herhalen. Dat kan tot een vaste plaats van auteurs, hun werken en de door hen vertegenwoordigde genres in de literaire markt leiden.

Het is ook mogelijk om antwoorden voor de in de inleiding gestelde vragen te formuleren. Het vertalen van de Nederlandse fantastische literatuur moet op dit moment in het domein van de pro publico bono uitgeverijen blijven, voordat de namen van de Nederlandse fantastische schrijvers bekend genoeg zijn in Polen om ze commercieel te publiceren - het aandeel van de commerciële uitgaven is nog heel laag. De functie van deze vertalingen is nu meer symbolisch dan materieel (Glas 20), ook dankzij de stijgende populariteit van elektronische tekstuitgaven. Toch is het wel mogelijk om klassiekers als Bilderdijk makkelijk in de buitenlandse markt uit te geven of om een meer populaire auteur te kiezen die al lokaal actief is. Zolang er actieve en Nederlands machtig vertalers aanwezig in Polen zullen zijn, is het wel mogelijk om meer dergelijke publicaties aan de markt te brengen.

Het meest worden Nederlandse fantasy en sciencefiction vertaald. Deze subgenres zijn dus veilig om te vertalen naar het Pools om meer zekerheid te hebben dat de teksten door de Poolse uitgever gepubliceerd zullen worden. Toch moeten de lezers en vertalers ook naar een balans zoeken tussen de drie subgenres: fantasy, sciencefiction en horror. Op het moment dat er veel werken van de twee subgenres al in het Pools bestaan, is het vertalen van de Nederlandse horrorliteratuur een subniche in het vertalen van het fantastische genre in het algemeen. Dat is dan een oproep aan alle instanties in het proces van het uitgeven van de buitenlandse (Nederlandse) fantastische literatuur om dit gat in te vullen, het liefst op een vergelijkbare manier als Szortal dat tot nu toe heeft gedaan - met gratis uitgaven bewerkt en vertaald 
door vrijwilligers. Hoewel deze oproep niet de belangrijkste stem in de discussie is, is het zeker, dat de Nederlands-Pools vertalers deze kwestie ook duidelijk (zullen) zien en daarop reageren met nieuwe voorstellingen van vertalingen in het fantastische genre, uiteraard in horrorverhalen.

\section{BIBLIOGRAFIE}

Alles is taal geworden. Geschiedenis van de Nederlandse literatuur. 1800-1900, onder redactie van Willem van den Berg \& Piet Couttenier. Bert Bakker, 2009.

Bel, Jacqueline. Bloed en rozen. Geschiedenis van de Nederlandse literatuur 1900-1945. Prometheus, 2018.

Boekstein, Jaap. De Kroniek van de Drie Zusters der Dromen. De Geschiedenis van het Science Fiction, Fantasy-en Horrorfandom in de Lage Landen. Deel 1. Het Begin - 1992. Bravado Books, 1992.

Brems, Hugo. Altijd weer vogels die nesten beginnen. Geschiedenis van de Nederlandse literatuur 1945-2005. Bert Bakker, 2016.

Czarnecka, Bożena. "De Nederlandstalige literatuur in de themanummers van Poolse literaire en algemeen-culturele tijdschriften na 1945". Werkwinkel, vol. 2, 2007, nr. 1, pp. 14-31.

Dowlaszewicz, Małgorzata, en Jerzy Koch. "Bibliografia przekładów z literatury niderlandzkiej”. Widzę rzeki szerokie... z dziejów literatury niderlandzkiej XIX i XX wieku. Tom 2, onder redactie van Jerzy Koch \& Piotr Oczko, Poznań, Biblioteka Werkwinkel, 2018, pp. 589-628.

Filkins, Peter. "A Multilingual Workshop in Poetry and Prose Translation.” Teaching Translation. Programs, Courses, Pedagogies, onder redactie van Lawrence Venuti, Routledge, 2017, pp. 87-93.

Glas, Frank de. "Methoden in het uitgeverijonderzoek. Een stand van zaken en een bericht uit de onderzoekspraktijk." Literatuurwetenschap en uitgeverijonderzoek, onder redactie van Kevin Absillis \& Kris Humbeeck, Gent, Academia Press, 2012, pp. 11-26.

Gorp, Hendrik van et al. Lexicon van Literaire Termen. Wolters-Noordhoff, 1991.

Hal, George van. "Toekomst (non-)fictie". de Volkskrant. Boeken \& Wetenschap, 13 juli 2019, pp. 4-6.

Kalla, Irena Barbara. "Receptie van Harry Mulisch in Polen”. Werkwinkel, vol. 2, nr. 1, 2007, pp. 33-49.

Letterkundig lexicon voor de neerlandistiek, onder redactie van Gerrit Jan van Bork. Digitale bibliotheek voor de Nederlandse letteren, 2002.

Lindeboom, Martijn, en Debbie van der Zande. Hoe schrijf je fantasy en sciencefiction? Atlas Contact, 2015

Majkowski, Tomasz Z. W cieniu białego drzewa. Powieść fantasy w XX wieku. Wydawnictwo Uniwersytetu Jagiellońskiego, 2013.

Morciniec, Dorota, en Norbert Morciniec. Historia literatury niderlandzkiej. Zarys. Zakład Narodowy im. Ossolińskich, 1985.

Oramus, Dominika. O pomieszaniu gatunków. Science Fiction a postmodernizm. Wydawnictwo TRIO, 2010. 
Paszkiet, Sławomir. "Report on the Situation of Literary Translators in Poland". Werkwinkel, vol. 8, nr. 2, 2013, pp. 123-139.

Pindel, Tomasz. Realizm magiczny. Przewodnik (praktyczny). Kraków, Universitas, 2014.

Prędota, Stanisław. Wprowadzenie do językoznawstwa niderlandzkiego. Wydawnictwo Uniwersytetu Wrocławskiego, 2003.

Smutny kos. Opowieści niesamowite i osobliwe z prozy niderlandzkiej, onder redactie van Ewa Dijk-Borkowska, Państwowy Instytut Wydawniczy, 1983.

Trębicki, Grzegorz. Fantasy. Ewolucja gatunku. Kraków, Universitas, 2007.

Zgorzelski, Andrzej. Fantastyka, utopia, science fiction. Państwowe Wydawnictwo Naukowe, 1980.

\section{GERAADPLEEGDE WEBSITES}

www1 - "Baza thumaczy". Stowarzyszenie Ttumaczy Literatury, stl.org.pl/baza-tlumaczy/. Raadgepleegd op 19.08.2020.

www2 - Encyklopedia Fantastyki, www.encyklopediafantastyki.pl/index.php?title=Strona główna. Geraadpleegd 19.08.2020.

www3 - "Ervaringen". Universiteit Utrecht, www.uu.nl/bachelors/literatuurwetenschap/ervaringen. Geraadpleegd 27.01.2020.

www4 - "Fantastisch schrijven" en "Harland Awards". Stichting ter bevordering van het fantastische genre, www.fantastischgenre.eu/fantastisch-schrijven/. Geraadpleegd 27. 01.2020 .

www5 - "Fantastische literatuur". Algemene letterkundig lexicon, www.dbnl.org/tekst/dela 012alge01_01/dela012alge01_01_00867.php. Geraadpleegd op 19.08.2020.

www6 - "Korte verhalen". Fantasywereld.nl, www.fantasywereld.nl/category/boeken/korte-ver halen/. Raadgepleegd op 02 februari 2020.

www7 - "Polskie przekłady literatury niderlandzkiej". Katolicki Uniwersytet Lubelski Jana Pawta II w Lublinie, www.kul.pl/polskie-przeklady-literatury-niderlandzkiej, art_90 490.html. Geraadpleegd 19.08.2020.

www8 - "Szortal - wsparcie finansowe". Zrzutka.pl, zrzutka.pl/gsre8y?utm_medium= social \&utm source=facebook\&utm_campaign=sharing_button\&fbclid=IwAR39rdSWqGVf7pswz8SS5q XAlH0QfoojAf6EvDUeZs31Q5mxN3m86yMEhsw. Geraadpleegd 26.11. 2020.

\section{NIDERLANDZKA LITERATURA FANTASTYCZNA W TŁUMACZENIU NA JEZZYK POLSKI}

\section{Streszczenie}

Niderlandzka literatura fantastyczna rozwija się i zajmuje coraz bardziej eksponowaną pozycję w literaturze i kulturze niderlandzkiej. Może to potwierdzać między innymi rosnące zainteresowanie twórczością pisarzy niderlandzkich swiecie. W artykule przedstawiono historię oraz tendencje w zakresie przekładów niderlandzkiej literatury fantastycznej na język polski. Omówiono także instytucje życia literackiego, podgatunki oraz formy publikacji niderlandzkiej fantastyki w języku polskim, zarysowując na tej podstawie tendencje panujące w polskiej kulturze literackiej.

\section{Przełożyła Beata Popławska}

Słowa kluczowe: niderlandzka fantastyka naukowa; niderlandzka fantasy; niderlandzka fantastyka; Willem Bilderdijk; Mike Jansen. 


\title{
DUTCH FANTASTIC LITERATURE IN POLISH TRANSLATION
}

\section{S u m m a r y}

Dutch fantastic literature is showing clear development in the formalisation and strengthening of its position in Dutch literature and culture. This can also be seen in the growing interest being paid to Dutch writers in foreign literature markets. This article shows the history and trends in the translation of Dutch fantastic literature into Polish. I discuss the different literary organisations, the subgenres, and the forms of the publication of Dutch fantastic literature in Polish in order to illustrate the tendencies of the Polish literary sphere.

Keywords: Dutch science fiction; Dutch fantasy; Dutch speculative fiction; Willem Bilderdijk; Mike Jansen.

\author{
BIJLAGE
}

\section{NEDERLANDSE FANTASTISCHE LITERATUUR IN POLEN ${ }^{1}$}

(op de volgende pagina's)

\footnotetext{
${ }^{1}$ Opmerking bij de tabel: vier werken uitgegeven in Szortal zijn niet meer beschikbaar, omdat ze alleen voor een korte periode online en in digitale vorm (.pdf, .mobi, .epub) beschikbaar waren.
} 


\begin{tabular}{|c|c|c|c|c|c|c|c|c|c|}
\hline 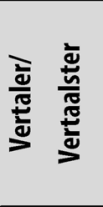 & 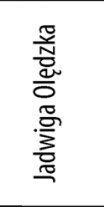 & 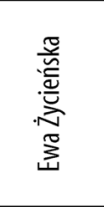 & 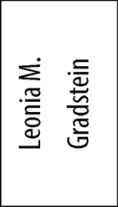 & 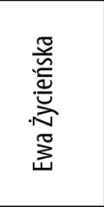 & 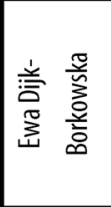 & 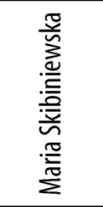 & \multicolumn{3}{|c|}{ 资 } \\
\hline 离 & $\stackrel{\infty}{\circ}$ & \multicolumn{3}{|c|}{$\stackrel{n}{\stackrel{2}{\sigma}}$} & ఏ̊ & ô & 品 & \multicolumn{2}{|c|}{ 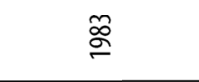 } \\
\hline ฏัँ & 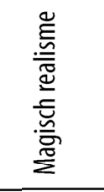 & 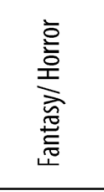 & 홓 & 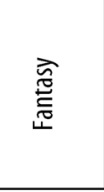 & 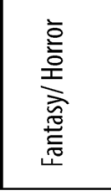 & 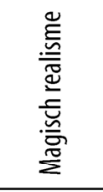 & \multicolumn{3}{|c|}{ 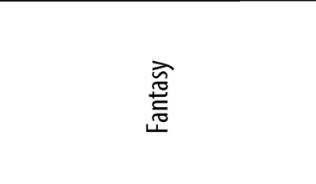 } \\
\hline 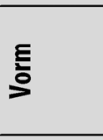 & 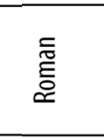 & \multicolumn{4}{|c|}{ 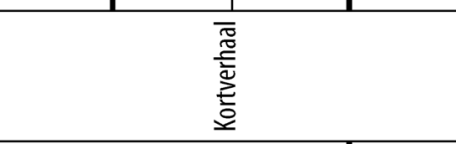 } & \multicolumn{2}{|c|}{ 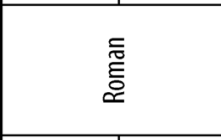 } & \multicolumn{2}{|c|}{ 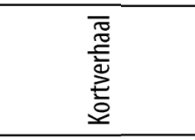 } \\
\hline $\begin{array}{l}\text { 产 } \\
\text { 吾 }\end{array}$ & 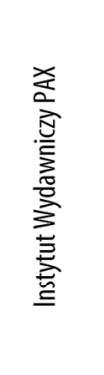 & \multicolumn{3}{|c|}{ 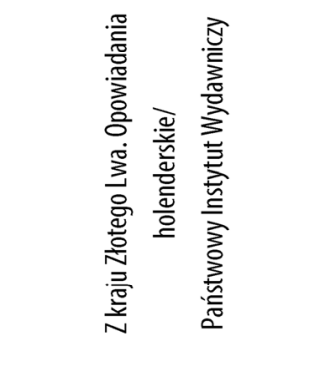 } & 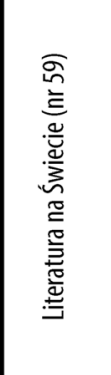 & 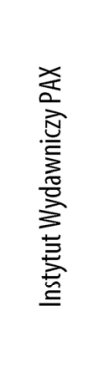 & 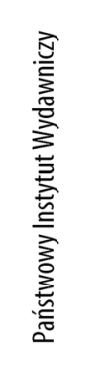 & \multicolumn{2}{|c|}{ 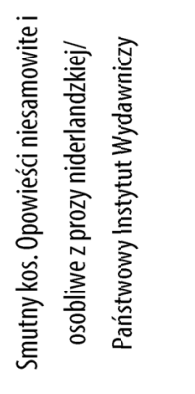 } \\
\hline 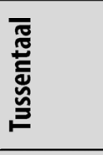 & $\dddot{ㄸ ㅗ}$ & \multicolumn{3}{|c|}{$\sim$} & $\not{z}$ & 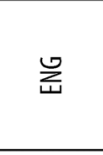 & \multicolumn{3}{|c|}{$\not \vec{z}$} \\
\hline 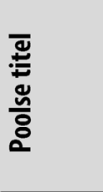 & 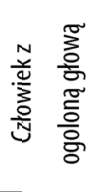 & 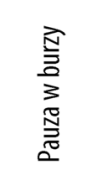 & 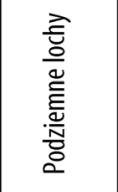 & 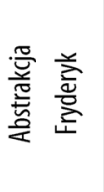 & 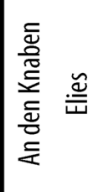 & 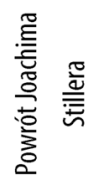 & 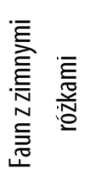 & 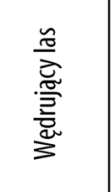 & 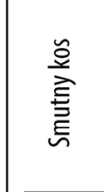 \\
\hline 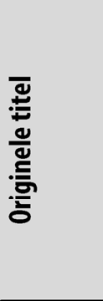 & 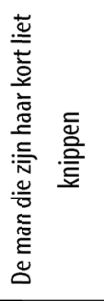 & 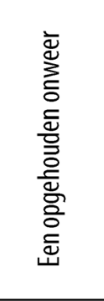 & 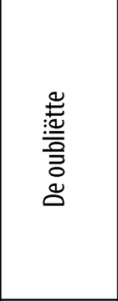 & 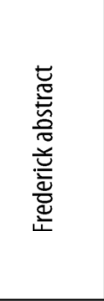 & 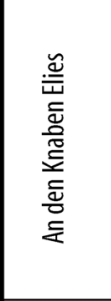 & 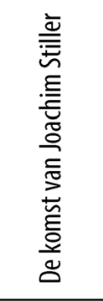 & 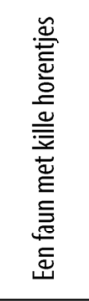 & 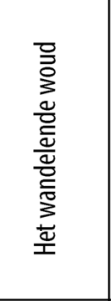 & 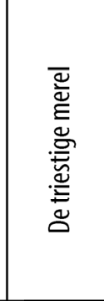 \\
\hline 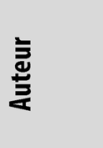 & 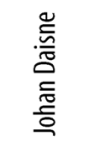 & 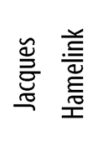 & 唇喜 & 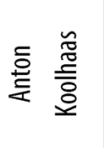 & 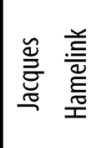 & 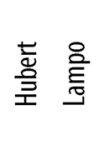 & $\begin{array}{l}\text { 造 } \\
\text { 产 } \\
\text { 全 }\end{array}$ & 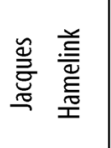 & \begin{tabular}{|l}
$\overline{\bar{z}}$ \\
产 \\
言 \\
咅
\end{tabular} \\
\hline
\end{tabular}




\begin{tabular}{|c|c|c|c|c|c|c|c|c|c|}
\hline 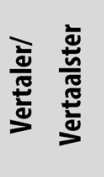 & & 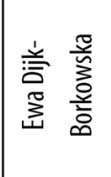 & 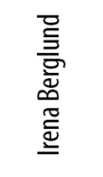 & 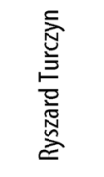 & 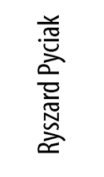 & 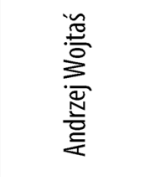 & 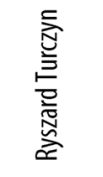 & 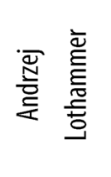 & 啚 \\
\hline \multicolumn{10}{|l|}{ 点 } \\
\hline 迆 & & & & & & 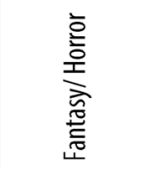 & $\begin{array}{l}\text { 育 } \\
\text { 悹 }\end{array}$ & \multicolumn{2}{|c|}{ 흫 } \\
\hline \multicolumn{10}{|l|}{ E् } \\
\hline \multicolumn{10}{|l|}{$\begin{array}{l}\text { 总 } \\
\text { 害 }\end{array}$} \\
\hline \multicolumn{10}{|l|}{ 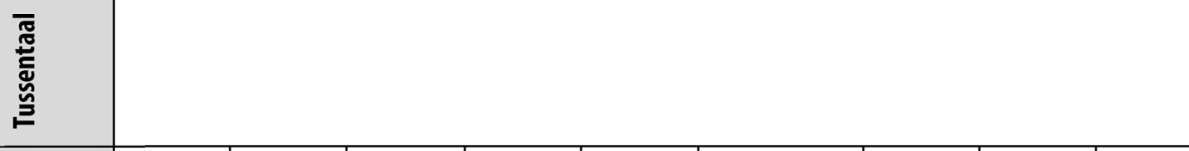 } \\
\hline 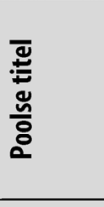 & 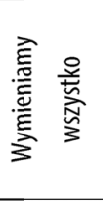 & 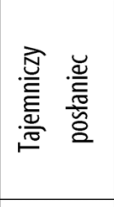 & 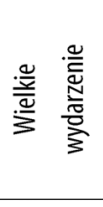 & 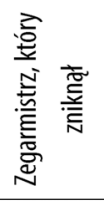 & 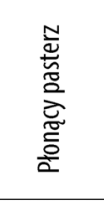 & 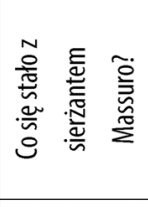 & 言 & 茎 & '⿳亠丷厂犬 \\
\hline 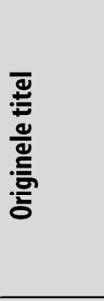 & 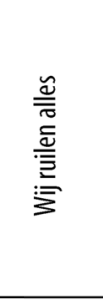 & 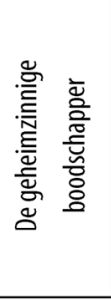 & 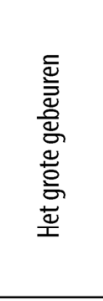 & 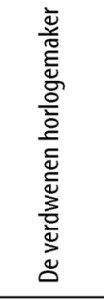 & 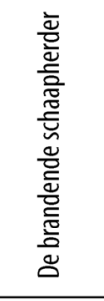 & 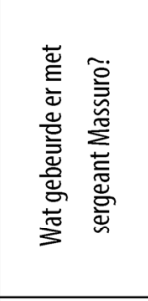 & 호 & 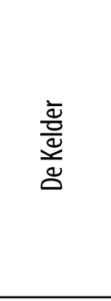 & 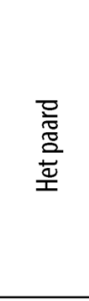 \\
\hline 䔍 & 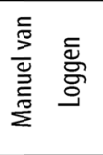 & $\stackrel{\cong}{\overline{\bar{z}}}$ & $\begin{array}{l}\text { 을 } \\
\frac{\bar{E}}{\Phi}\end{array}$ & 毫喜 & 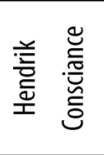 & 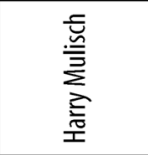 & 总旁 & 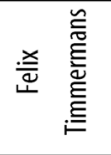 & 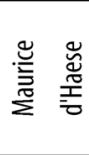 \\
\hline
\end{tabular}




\begin{tabular}{|c|c|c|c|c|c|c|c|c|c|c|c|}
\hline 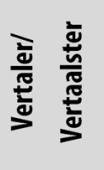 & 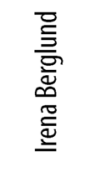 & \multicolumn{2}{|c|}{ 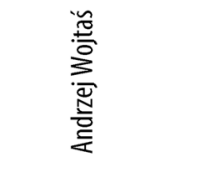 } & \multicolumn{5}{|c|}{ 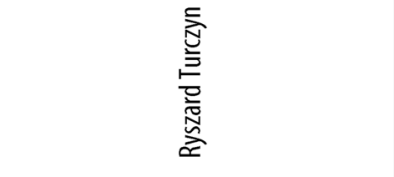 } & 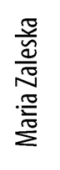 & 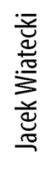 & 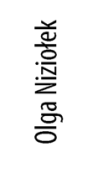 \\
\hline 丞 & & & & \multicolumn{5}{|c|}{$\stackrel{\stackrel{\circ}{\circ}}{\circ}$} & 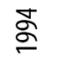 & ఫ్రి & $\stackrel{m}{\grave{n}}$ \\
\hline & & 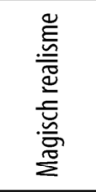 & 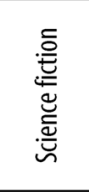 & 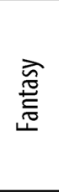 & \multicolumn{4}{|c|}{ 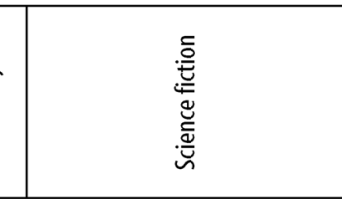 } & \multicolumn{2}{|c|}{ 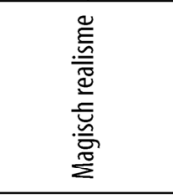 } & 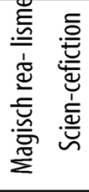 \\
\hline E् & & \multicolumn{7}{|c|}{ 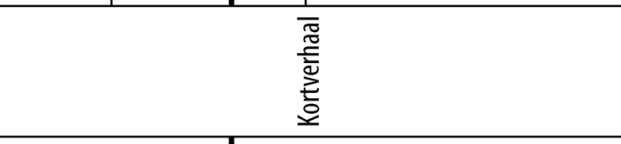 } & \multicolumn{2}{|c|}{$\begin{array}{l}\text { 흘 } \\
\text { 产 }\end{array}$} & 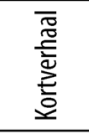 \\
\hline $\begin{array}{l}\stackrel{5}{5} \\
\stackrel{5}{5}\end{array}$ & & 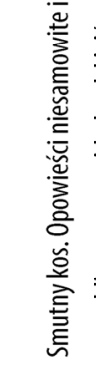 & 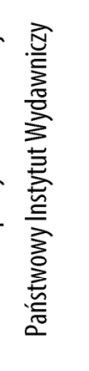 & \multicolumn{5}{|c|}{ 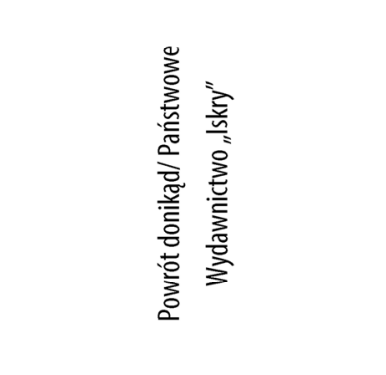 } & 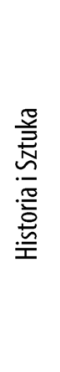 & 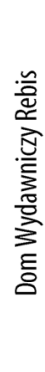 & 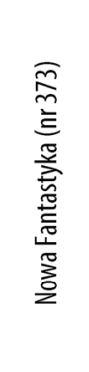 \\
\hline 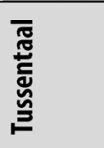 & & \multicolumn{8}{|c|}{$\not \vec{z}$} & \multicolumn{2}{|c|}{ 号 } \\
\hline 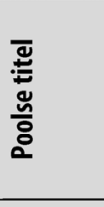 & 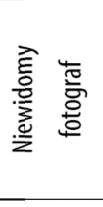 & 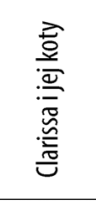 & 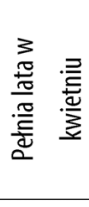 & 焉 & 恙 & 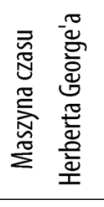 & 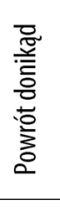 & 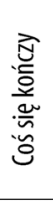 & 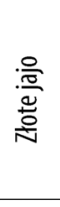 & 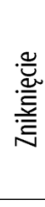 & 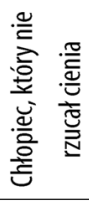 \\
\hline 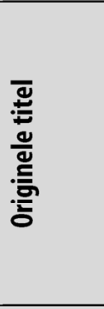 & 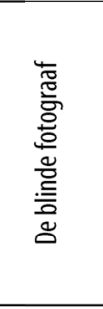 & 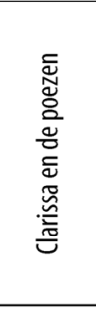 & 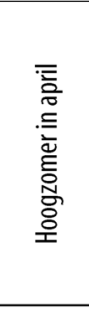 & 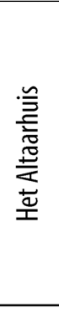 & $\begin{array}{l}\text { 恙 } \\
\text { 品 }\end{array}$ & 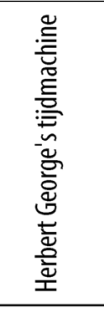 & 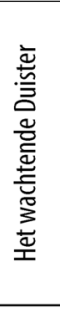 & 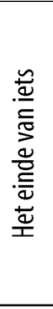 & 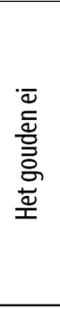 & 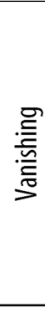 & 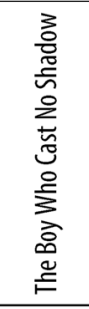 \\
\hline 䓌 & 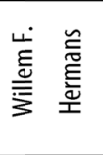 & $\begin{array}{l}\text { 壳 } \\
\text { 尊 }\end{array}$ & 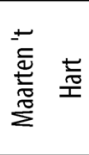 & & & 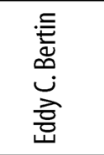 & & & ही & & 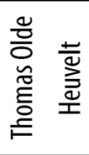 \\
\hline
\end{tabular}




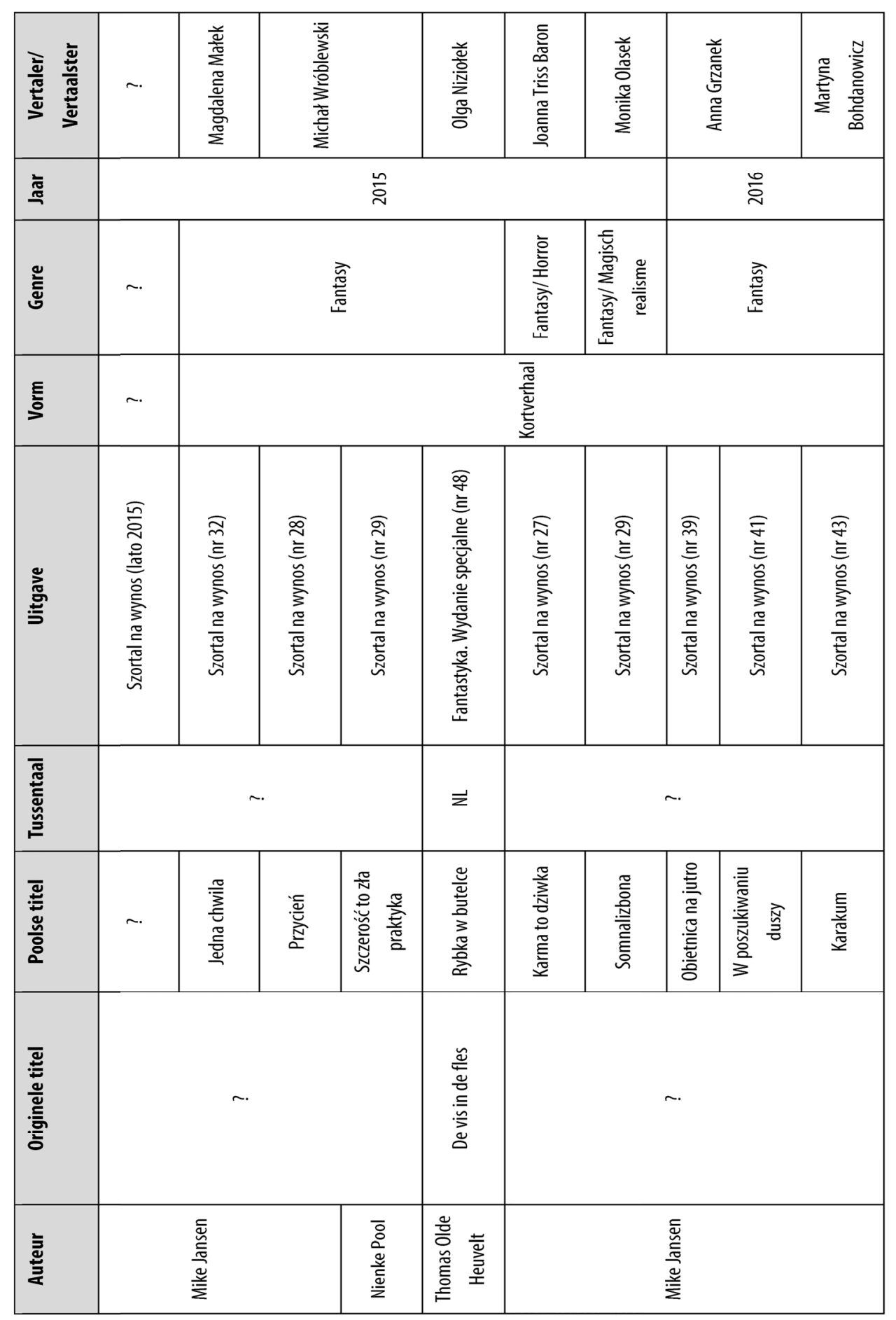




\begin{tabular}{|c|c|c|c|c|c|c|c|c|c|c|}
\hline 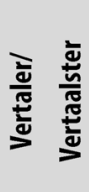 & 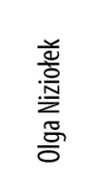 & 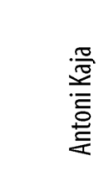 & & 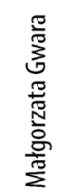 & 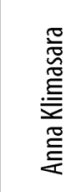 & $\begin{array}{l}\frac{\pi}{\pi} \\
\frac{3}{0} \\
\frac{\pi}{\pi} \\
\frac{1}{2} \\
\frac{c}{2}\end{array}$ & & 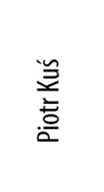 & \multicolumn{2}{|c|}{ 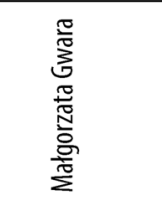 } \\
\hline 营 & \multicolumn{4}{|c|}{ 离 } & \multicolumn{6}{|c|}{$\overline{\grave{D}}$} \\
\hline 芯 & 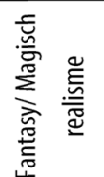 & 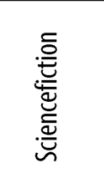 & \multicolumn{3}{|c|}{ 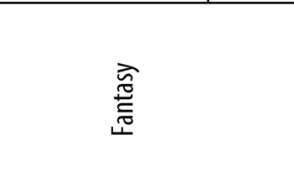 } & \multicolumn{3}{|c|}{ 홓 } & \multicolumn{2}{|c|}{ 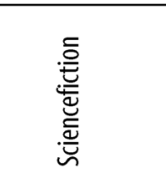 } \\
\hline E⿱亠䒑口心 & & & & & 毫 & 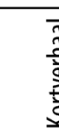 & & 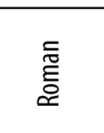 & & \\
\hline $\begin{array}{l}\text { 总 } \\
\text { 写 }\end{array}$ & 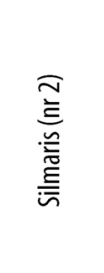 & 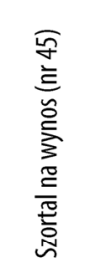 & \multicolumn{2}{|c|}{ 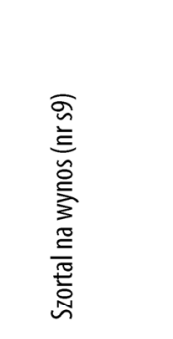 } & 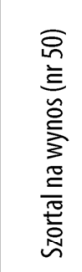 & 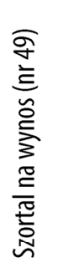 & 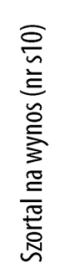 & 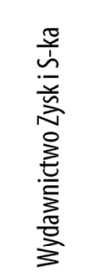 & 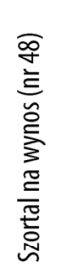 & 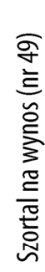 \\
\hline 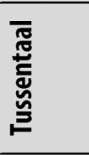 & & & & & & & & $\stackrel{D}{\underline{z}}$ & \multicolumn{2}{|c|}{$\sim$. } \\
\hline 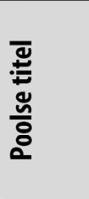 & 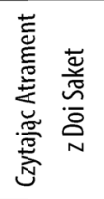 & 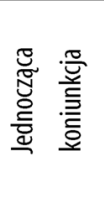 & 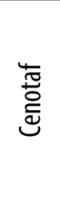 & 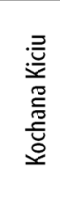 & 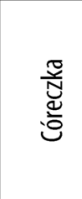 & 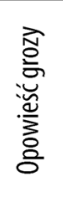 & 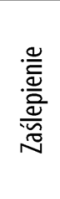 & ج্ج & 营 & 莺 \\
\hline 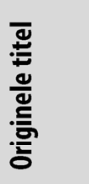 & & & & & & & & ج্ج & ? & \\
\hline 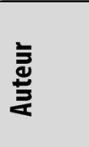 & 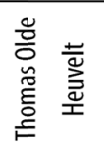 & $\begin{array}{l}\overline{\bar{\nu}} \\
\text { 产 } \\
\text { 产 } \\
\text { 妾 }\end{array}$ & 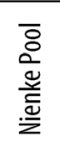 & & 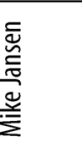 & & 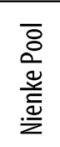 & 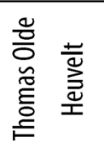 & 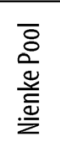 & 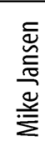 \\
\hline
\end{tabular}




\begin{tabular}{|c|c|c|c|c|c|c|c|c|c|c|c|}
\hline 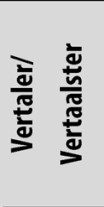 & $\sim$ & & 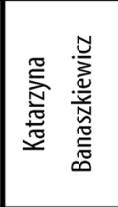 & 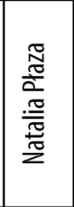 & 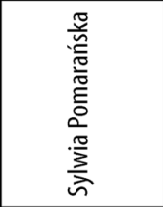 & & 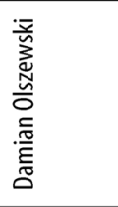 & 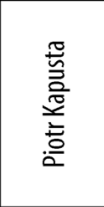 & 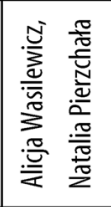 & 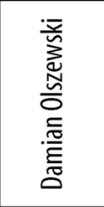 & 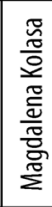 \\
\hline 犃 & \multicolumn{11}{|c|}{$\stackrel{\infty}{\stackrel{0}{\nu}}$} \\
\hline 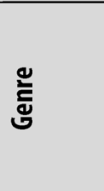 & $\sim$ & & \multicolumn{3}{|c|}{ 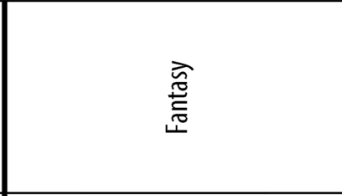 } & \multicolumn{2}{|c|}{ 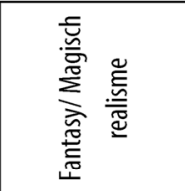 } & 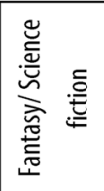 & & \multicolumn{2}{|l|}{ 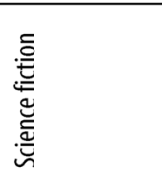 } \\
\hline E్ & \multicolumn{2}{|l|}{$\sim$} & \multicolumn{9}{|c|}{ 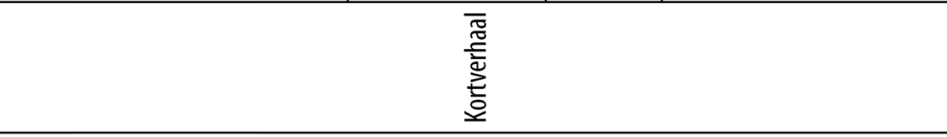 } \\
\hline $\begin{array}{l}\text { 認 } \\
\text { : } \\
\text { s }\end{array}$ & 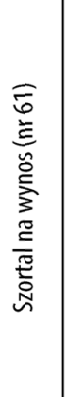 & 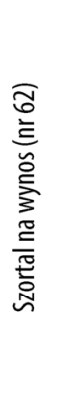 & \multicolumn{9}{|c|}{ 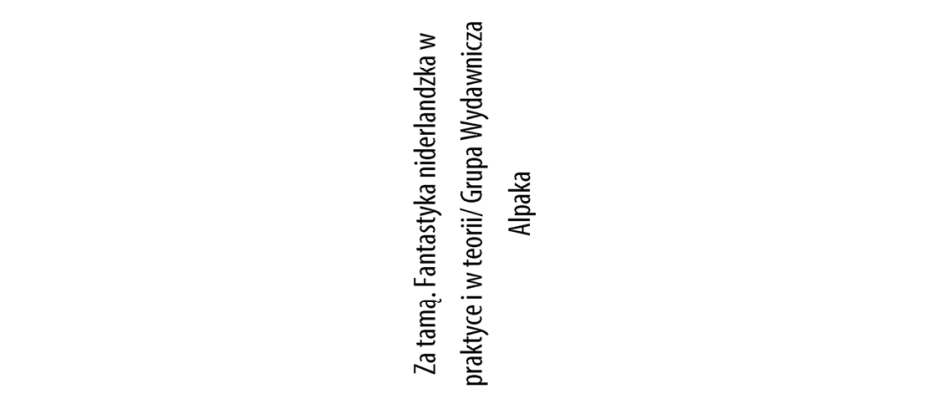 } \\
\hline 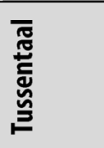 & & & $\not z$ & ¿ & \multicolumn{4}{|c|}{$\vec{z}$} & 롤 & $\not \vec{z}$ & 号 \\
\hline 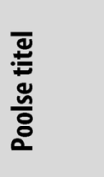 & $\sim$ & & 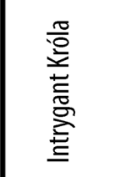 & 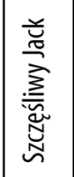 & 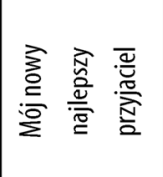 & 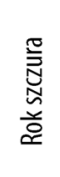 & 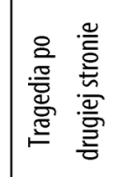 & 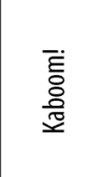 & 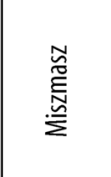 & 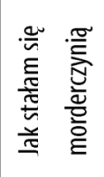 & 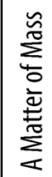 \\
\hline 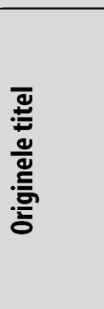 & & & 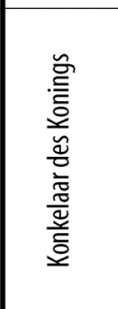 & 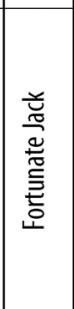 & 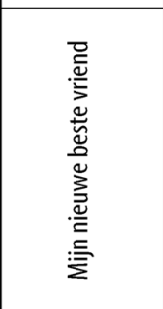 & 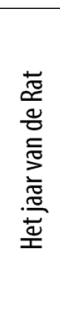 & 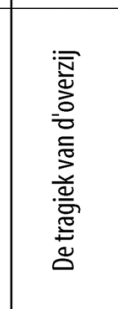 & 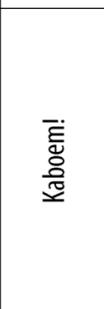 & $\begin{array}{l}\text { 产 } \\
\text { 离 }\end{array}$ & 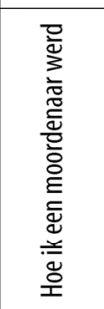 & 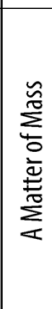 \\
\hline 竞 & & & 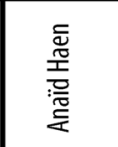 & & 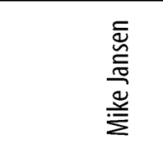 & & & 总离 & 玄 & 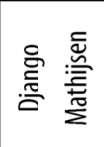 & 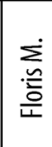 \\
\hline
\end{tabular}




\begin{tabular}{|c|c|c|c|c|c|c|c|c|c|c|c|c|}
\hline 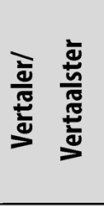 & & \multicolumn{2}{|l|}{ 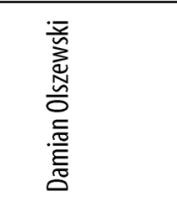 } & 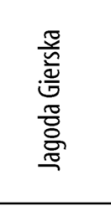 & 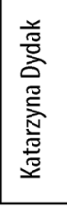 & 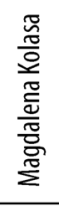 & 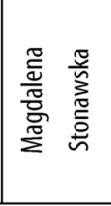 & 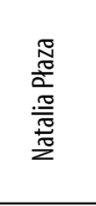 & \multicolumn{2}{|c|}{ 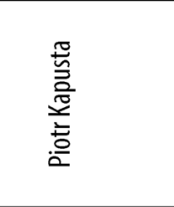 } & \multicolumn{2}{|c|}{ 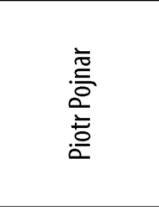 } \\
\hline \multicolumn{13}{|l|}{ 怘 } \\
\hline \multicolumn{13}{|c|}{ 莺 } \\
\hline \multicolumn{13}{|l|}{ E्ㅎㅎ } \\
\hline \multicolumn{13}{|l|}{ 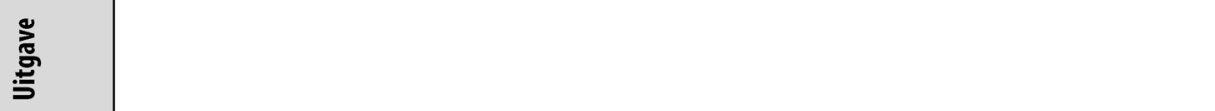 } \\
\hline 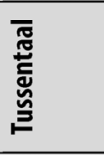 & & \multicolumn{4}{|c|}{$\vec{z}$} & \multicolumn{2}{|r|}{ 总 } & \multicolumn{5}{|c|}{$\ddot{z}$} \\
\hline 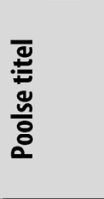 & & $\begin{array}{l}\text { 愛 } \\
\text { 产 } \\
\text { 定 }\end{array}$ & 䇈 & 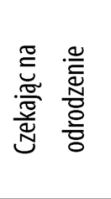 & $\begin{array}{l}\text { 帝 } \\
\sum_{0}^{5} \\
\frac{0}{0}\end{array}$ & 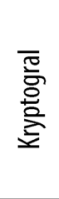 & 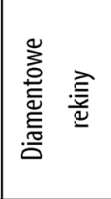 & 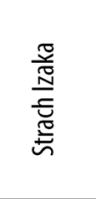 & 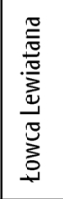 & 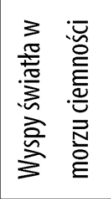 & 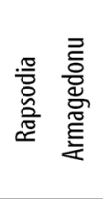 & 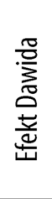 \\
\hline 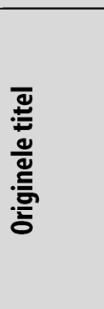 & & 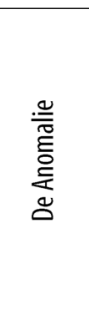 & $\frac{\overline{0}}{\frac{5}{0}}$ & 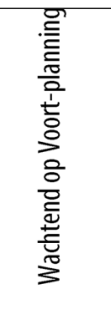 & 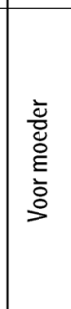 & 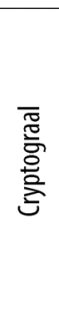 & 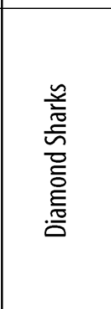 & $\begin{array}{l}\text { 蒙 } \\
\text { 产 } \\
\text { 音 }\end{array}$ & 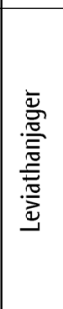 & 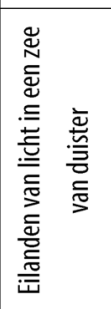 & 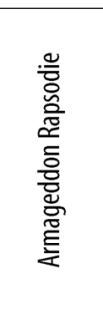 & 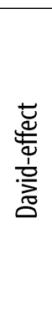 \\
\hline 竎 & $\frac{气}{\frac{\tilde{\bar{\theta}}}{\underline{x}}}$ & 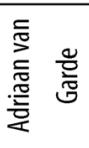 & 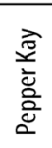 & 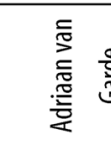 & & 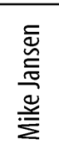 & 恴訔 & 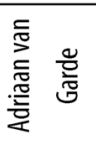 & & 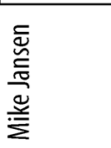 & 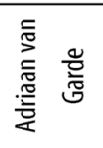 & 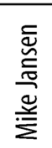 \\
\hline
\end{tabular}




\begin{tabular}{|c|c|c|c|c|c|c|}
\hline 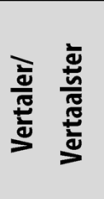 & $\sim$ & 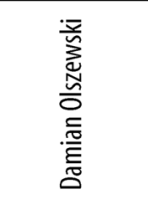 & \multicolumn{2}{|c|}{ 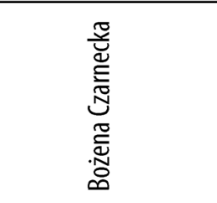 } & 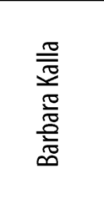 & 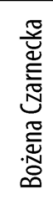 \\
\hline 前 & \multicolumn{6}{|c|}{$\stackrel{\text { ¿े }}{\circ}$} \\
\hline 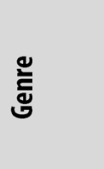 & $\sim$ & 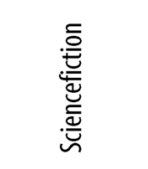 & $\begin{array}{l}\text { 产 } \\
\text { 悹 }\end{array}$ & 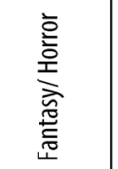 & 흫 & 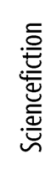 \\
\hline 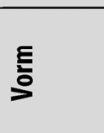 & $\sim$ & $\begin{array}{l}\frac{\mathrm{o}}{\overline{\underline{v}}} \\
\frac{\overrightarrow{0}}{2}\end{array}$ & \multicolumn{4}{|c|}{ 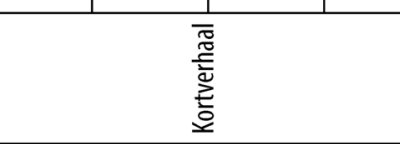 } \\
\hline $\begin{array}{l}\text { 芯 } \\
\text { : } \\
\text { s }\end{array}$ & 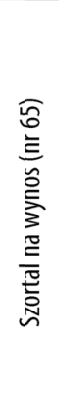 & 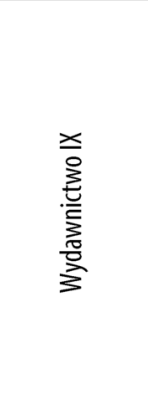 & \multicolumn{4}{|c|}{ 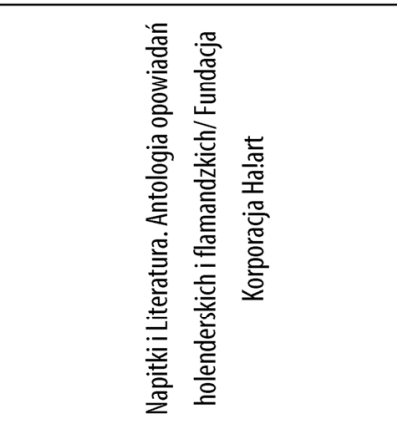 } \\
\hline 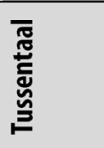 & $\sim$ & \multicolumn{5}{|c|}{$\not \vec{z}$} \\
\hline 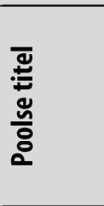 & $\sim$ & 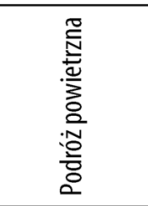 & 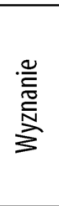 & 萨 & 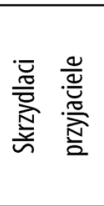 & 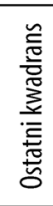 \\
\hline 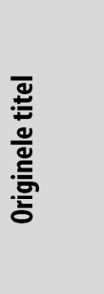 & $\sim$ & 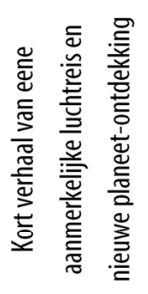 & 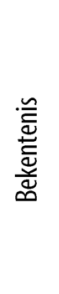 & 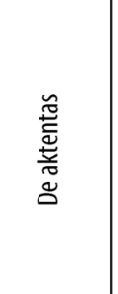 & 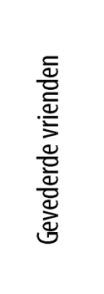 & 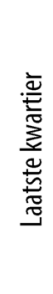 \\
\hline 亮 & & 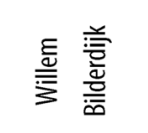 & 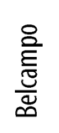 & 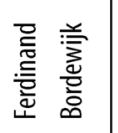 & & \\
\hline
\end{tabular}

